\begin{tabular}{|r|l|l||}
\hline Received: Desember 2018 & Accepted: Januari 2019 & Published: Januari 2019 \\
\hline \hline Article DOI: $\underline{\text { http://dx.doi.org/10.24903/jam.v3i1.390 }}$ \\
\hline
\end{tabular}

\title{
Pelatihan Pembuatan Saus Dari Limbah Kulit Buah Naga Merah Sebagai Saus sehat di Jalan Raudah Rt. 10 Kelurahan Teluk Lerong Kecamatan Samarinda Ulu
}

\author{
Yulistia Budianti Soemarie \\ Akademi Farmasi Samarinda \\ yulistiabudianti@ymail.com \\ Anita Apriliana \\ Akademi Farmasi Samarinda \\ pushing_ahh@yahoo.com
}

\begin{abstract}
Abstrak
Daerah padat penduduk di Samarinda Kalimantan Timur salah satunya adalah Kelurahan Teluk Lerong. Didaerah ini terdapat banyak pedagang bakso, nasi goreng dan jajanan gorengan. Sebagian besar pedagang ini menggunakan bahan pelengkap berupa saus baik saus cabai maupun saus tomat. Mahalnya saus kemasan, mengakibatkan sebagian besar pedagang menggunakan saus kiloan dengan harga murah. Permasalahan yang dihadapi adalah minimnya pengetahuan mengenai dampak kesehatan penggunaan saus kiloan yang tidak terjamin mutu dan kualitasnya, mengakibatkan terjadinya penurunan derajat kesehatan di masyarakat. Hal ini juga menjadi perhatian bagi para ibu rumah tangga dalam mensiasati pembuatan saus dengan kualitas baik, aman bagi kesehatan keluarga dan harga murah.

Solusi yang diberikan dari masalah diatas adalah dengan memberikan pelatihan kepada para ibu-ibu yang berada di Kelurahan Teluk Lerong (Jalan Raudah RT. 10) dalam pembuatan saus dari limbah kulit buah naga merah sebagai saus sehat untuk keluarga. Adapun peserta dari pelatihan ini adalah para ibu-ibu yang tergabung dalam kelompok pengajian Raudhatul Khair. Pelatihan ini dibagi menjadi 3 materi, yaitu materi mengenai nilai gizi dan kandungan dari saus dan buah naga merah, praktek pembuatan saus dari kulit buah naga merah dan pelatihan pengemasan saus.
\end{abstract}

Kata Kunci : Kulit Buah Naga Merah, Saus, Kelurahan Teluk Lerong Samarinda 


\section{(A) ABDIMAS \\ https://journal.uwgm.ac.id/index.php/abdimasmahakam/index}

E-ISSN: 2549-5755

Januari 2019, Vol. 3 No. 1

\section{Pendahuluan}

Salah satu daerah padat penduduk di Samarinda Kalimantan Timur yang terdapat banyak sekali pedagang makanan salah satunya berada di daerah Kelurahan Teluk Lerong. Di Kelurahan Teluk Lerong ini banyak sekali pedagang yang menjajakan dagangannya seperti nasi goreng, mie ayam dan bakso. Di sekitar Kelurahan ini juga terdapat sekolah dari SD, SMP maupun SMA. Banyaknya sekolah yang berada pada daerah ini merupakan lahan bagi para penjual jajanan seperti pentol, cilok dan sosis goreng. Bumbu pelengkap dari penjual jajanan ataupun makanan ini salah satunya adalah saus. Saus merupakan bumbu penyedap makanan yang berfungsi meningkatkan cita rasa sehingga makanan lebih lezat. Selain melezatkan, saus (tomat) juga menambah gizi makanan karena secara keseluruhan gizi saus (tomat) lebih tinggi dibandingkan dengan buah tomat (Setyarini dkk, 2010).

Namun terdapat beberapa hal kecurangan yang dilakukan produsen pembuat saus murahan yaitu tidak menggunakan bahan baku yang segar ataupun menggunakan zat pewarna tekstil untuk memikat konsumen dari warna saus tersebut. Adanya cemaran biologi juga mempengaruhi kualitas dari saus tomat. Cemaran biologi disebabkan oleh berbagai bakteri seperti bakteri anaerob Salmonella, Shigella, Staphyllococcus aureus, Streptococcus faecalis, Vibrio dan lain sebagainya (Depkes, 2002). Saus yang umumnya diperjualbelikan di Indoensia adalah saus cabai dan saus tomat. Namun demikian, ada juga yang memproduksi saus pepaya tetapi biasanya pepaya hanya digunakan sebagai bahan campuran (Erliza, 2007). Mahalnya bahan baku utama dari pembuatan saus, seperti cabai dan tomat, membuat para produsen meningkatkan harga jual dari saus. Hal ini mengakibatkan para pedagang jajanan biasanya menggunakan saus curah ataupun saus yang tidak memiliki merek, yang dijual dalam kemasan kiloan dengan harga yang cukup murah. Saus curah ini juga seringkali digunakan oleh para ibu rumah tangga sebagai bumbu pelengkap pada masakannya. Jika hal ini dibiarkan maka akan berpengaruh buruk terhadap tingkat kesehatan keluarga. Sehingga perlu dicari suatu solusi yang dapat mengatasi permasalahan tersebut.

\section{Metode}

Peserta pelatihan pembuatan saus ini adalah para ibu-ibu pengajian Raudhatul Khair yang terdapat di Jalan Raudah RT. 10 Kelurahan Teluk Lerong Samarinda Kalimantan Timur. Para ibu-ibu pengajian ini sebagian besar adalah para ibu rumah tangga yang menggunakan saus sebagai salah satu bahan pelengkap dalam pembuatan makanan. Metode pelatihan dilakukan dengan ceramah, praktek dan diskusi.

Pelaksanaan pengabdian ini dilakukan dengan tahapan sebagai berikut :

1. Melakukan survey lokasi dan perjanjian kerjasama dengan ketua ibu-ibu pengajian Raudhatul Khair di gang Raudah RT. 10 Kelurahan Teluk Leorng Samarinda Ulu Kalimantan Timur. Pada pertemuan ini juga disampaikan susunan rencana kegiatan selama melakukan pengabdian.

2. Penyusunan jadwal kegiatan

Kegiatan ini dilakukan 2 kali pertemuan. Pertemuan pertama dilakukan pelatihan/praktek pembuatan saus dari kulit buah naga merah, dan pertemuan kedua dilakukan penyuluhan 


\section{(A) ABDIMAS \\ https://journal.uwgm.ac.id/index.php/abdimasmahakam/index}

E-ISSN: 2549-5755

Januari 2019, Vol. 3 No. 1

mengenai nilai gizi dan kandungan dari saus dan buah naga merah serta penyuluhan bagaimana pengemasan yang baik untuk saus tersebut.

3. Pelatihan pembuatan saus dari kulit buah naga merah

Pada tahapan ini, dilakukan persiapan alat dan bahan yang digunakan. Adapun alat yang digunakan berupa baskom, kompor dan gas, talenan, dandang (untuk mengukus), wajan, blender serta pisau. Adapun bahan yang digunakan yaitu, kulit buah naga merah, minyak goreng, bawang Bombay, bawang merah, bawang putih, merica, garam, gula, cabe rawit, cuka dan penyedap rasa.

4. Penyuluhan nilai gizi dan kandungan dari saus dan buah naga merah, serta cara pengemasan yang baik.

Penyuluhan ini dilakukan dengan metode ceramah dan diskusi dengan para peserta pengabdian, dalam hal ini ibu-ibu pengajian Raudhatul Khair.

\section{Hasil dan Pembahasan}

Pertemuan pertama pada kegiatan pengabdian masyarakat ini adalah pelatihan pembuatan saus dari kulit buah naga merah. Peserta pengajian yang mengikuti pelatihan ini sebanyak 40 orang. Penyuluh sebelumnya mempersiapkan peralatan dan bahan yang akan digunakan pada pelatihan tersebut. Sebelum mempraktekkan pembuatan saus, peserta diberikan ceramah mengenai tahapan pembuatan saus. Saus pada umumnya menggunakan daging buah, tetapi dalam hal ini tim pengabdian menginovasikan limbah dari buah naga merah yaitu berupa kulit yang diolah menjadi saus. Pada pertemuan ini, antusias peserta sangat terlihat. Hal ini dapat dilihat dari banyaknya pertanyaan yang diajukan. Beberapa pertanyaan tersebut misalnya mengenai pemilihan kulit dari buah naga merah, penggunaan bahan tambahan makanan lain, seperti pewarna ataupun mengenai waktu expiredate saus dalam penyimpanan. Selain itu cara pengolahan saus dari kulit buah naga merah yang sederhana, membuat para peserta menjadi ingin mencoba dirumah. Selama ini, mereka mengetahui bahwa saus hanya dapat diolah dari bahan baku tomat saja. peserta tidak menyangka, jika limbah dari buah naga merah masih bisa dimanfaatkan menjadi saus sehat yang bisa digunakan sebagai bahan tambahan makanan misalnya dalam pembuatan nasi goreng atau yang lainnya.

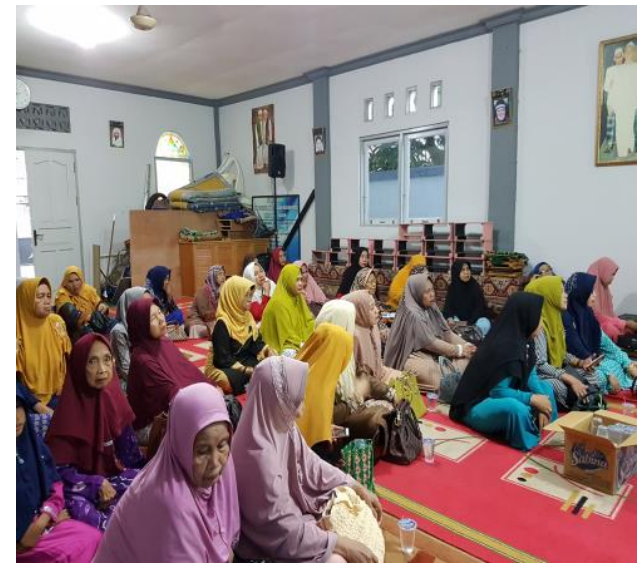

Gambar 1 : Peserta pelatihan dari kelompok pengajian Raudhatul Khair

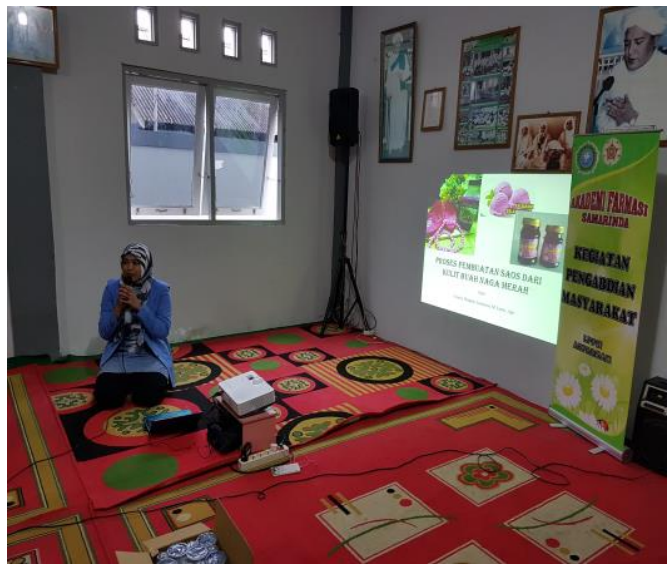

Gambar 2 : Penjelasan tahapan pembuatan saus dari kulit buah naga merah oleh penyuluh 


\section{(A) ABDIMAS}

https://journal.uwgm.ac.id/index.php/abdlimasmahakam/index

E-ISSN: 2549-5755

Januari 2019, Vol. 3 No. 1

Pertemuan kedua pada kegiatan pengabdian masyarakat ini berupa penyuluhan mengenai nilai gizi dan kandungan yang terdapat pada saus dan buah naga merah. Selain itu, pertemuan ini juga membahas pengemasan yang baik selama masa penyimpanan. Untuk nilai gizi, tim memberikan materi bahwa kandungan gizi dari buah naga merah sangat baik bagi kesehatan karena memiliki antioksidan yang tinggi dalam menangkal radikal bebas.

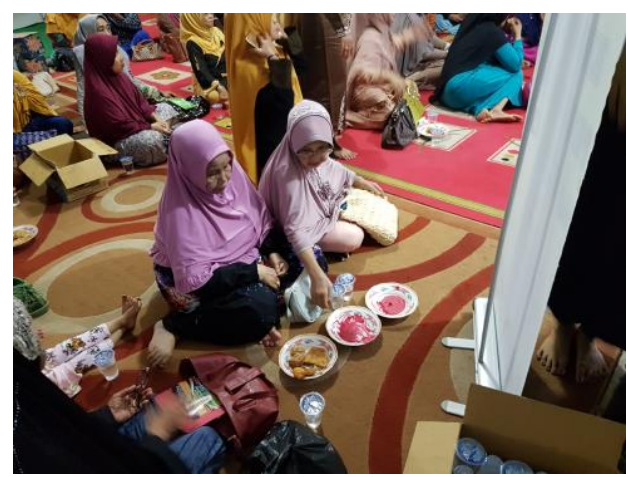

Gambar 3 : Para peserta mencicipi hasil pembuatan saus dari kulit buah anga merah

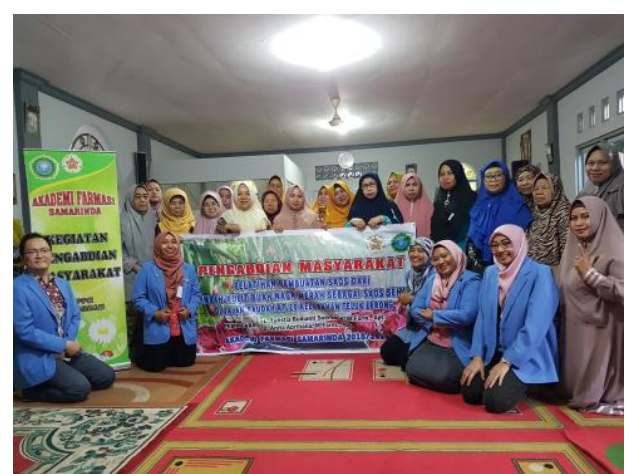

Gambar 4 : Foto bersama antara penyuluh dan peserta pengabdian masyarakat

\section{Simpulan dan Rekomendasi}

1. Peserta dapat mempraktekan cara pengolahan limbah kulit buah naga merah menjadi saus sehat.

2. Peserta memahami kandungan dan nilai gizi serta pengemasan yang baik bagi saus buah naga merah. 


\section{(A) ABDIMAS}

https://journal.uwgm.ac.id/index.php/abdlimasmahakam/index

E-ISSN: 2549-5755

Januari 2019, Vol. 3 No. 1

\section{Daftar Pustaka}

Departemen Kesehatan Republik Indonesia. 2002. Profil Kesehatan Sehat, Depkes RI, Jakarta Erliza. 2007. Sejarah Saus Sambal. Dikutip dari http://ilmu kefarmasian.blogspot.com/2012/11/saos-sambal.htmls, diakses tanggal 2 Agustus 2018.

Setyarini, D., Subiantoro, S., Selviawati. 2010. Identifikasi Bahan Pewarna dan Pengawet Pada Saos Tomat Yang Beredar Di Kota Jember. Stomatognatic (J.K.G) Vol. 7 No. 1 pp. 37-44. Universitas jember. 